\title{
Maritime English - Teaching Competencies in Facilitating Difficulties with Students
}

\author{
Evis CELO ( PhD) \\ Dr. Lorenc DANAJ \\ Jonil CELO Msc.
}

University “Ismail Qemali”, "Pavarësia” Square, Department of Foreign Languages Vlora, Albania,

evis.celo8@gmail.com

\begin{abstract}
Recognizing ship operating which differ in their organizing way helps in prevention of human injuries ;loss of life and avoidance of damage to the environment,in particular to the maritime environment and its property. The main aim is developing English for Maritime and having the right communication in different, specific and also in dangerous situation at sea. This paper consist on recognizing deeply the IMO standard on sea level including the IMO convention; SOLAS convention, MARPOL as well as STCW certificate and code too. So, advancing knowledge, understanding properly the right message at the sea including proficiency in having adequate knowledge of English language in order to enable officers \& new students to communicate with other ships \& coast stations to perform the officers duties. A great importance is based on cooperation of standard Marine Communication Phrases and use of International English both in written and oral form.. Not only that,but also multilingual communication crew, including abilities to use the IMO standard with Marine Communication Phrases! Difficulties and progresses are evident, but the necessity and the particular availability of Modern and Post Modern time let upon us this task open!
\end{abstract}

Keywords: Maritime Industry, Adequate Knowledge, International Convention, Security, Language Communication.

\section{INTRODUCTION}

At a time when effective communication on board between ship and shore is essential and especially in university classes it comes as a necessity to overall difficulties. Global standards governing communicative competence have been strengthened by IMO through its legal instruments and different conventions. It is now recognized that globalization of maritime services, including the supply of seafarers, has led to the adoption of Maritime English as a career tool and useful knowledge for the students of Naval and Nautical sciences, permitting not only mobility and flexibility but also competitiveness to face different situations.

In such circumstances national and international authorities, universities,training institutions need to develop effective strategies which meet these new demands of trade market. As a result we as Teaching Competencies and in terms of profession the delivery of Maritime English courses is important overall.

Consequently the main is aim to upgrade the full understanding, to introduce Maritime English with contemporary methodologies and useful practices. The understanding of the principles of communicative languages as promoted by IMO model course of 3.17, are also integrating these into my teaching process. I do consider that the selective materials of IMO's Standard Marine Communication Phrases (SMCP) give to the teachers a new horizon in order to create new methods during teaching Course materials in University aula.

\section{1 Expected outcome of students learning}

It is expected that at the end of the semester: 
Students should become fully aware of why is required the contemporary Maritime English?

1) To fulfil at least the basic demands of IMO's legal instruments, its advisory Model Course 3.17 and IMO's Standard Marine Communication Phrases (SMCP)

Students should have an understanding of the current knowledge of the available resources.

2) In order to teach and assess Maritime English competencies

Students should be in a position to develop and integrate the competencies discussed.

3) In order to adapt into the work situation, and share them with colleagues

Be prepared to embark upon a sustained process of self-directed skills development.

\section{NEW TECHNOLOGIES FOR SPECIFIC ACQUISITION OF MARITIME ENGLISH. THE LEVEL OF KNOWLEDGE IN THESE SUBJECTS.}

\section{1) The situation of students at the beginning of the academic year.}

As every beginning of each academic year, students and teachers has a lot to overcome in order to achieve the laying of track for a whole year and then bringing the train (the students) in the right destination.

Students of the University "Ismail Qemali" are showing a satisfactory level, which is reflective of a adeguate teaching value of English language.

Students mentioned above as each academic year are ing the shortcomings of their foreign language as a result of negligence, deconcentration, but at the same time I should not exclude the diversity of a language that they carry from cities and different treatises in the English language that they are given by English teachers.

Here I emphasize that specific English is not taken into account during teaching in schools.

What I am trying to face and to lessen Firstly there was to highlight the linguistic defects, to repair and insurance lexical grammatical concepts and functions of communication and hearing, which are very important during the proceedings on the ship and on the high seas.

This informs exactly students how to appropriate terminology that is used at sea in English and also to the respect all conventions and international agreements that naval officers are obliged to respect the negotiations on the high seas and in necessary steering as well as dangerous ones.

\section{2) Students state at the end of the semester.}

At the end of semester students show an improvement period of the previous situation. All this was based on new practices enabling authentic development of fluency, appropriate to their age, interests and level of their experience I mean linguistic one.

Students have become aware of the key concepts underlying the teaching methods used in particular for the importance of communicating.

\section{Naturally the Question arises about what was worth it?}

This awareness has encouraged students to ask questions to perform a event, a description (or essay), to classify the concepts obtained and gaps created both now and before. 
So, consciously it has enabled the practice of foreign language areas and conceptual development which means the development of thinking in the foreign language, in particular in English specifically in Maritime English even as a little bit is called a bilateral achievement both for the student and for the teacher.

\section{3) The consistently status of students and controls exercised.}

During the controls made in continuity it has been noticed that in addition to negligence displayed at specific individuals, students while taking on new responsibilities,unknown for the cooperation and interaction in the classroom related to communication in the foreign language, they can adjust the individual English speech to personal benefits in learning process by utilizing specific English terminology for marine engineering. Knowledge, skills and attitudes concerning foreign language and learning process will continue to be recovered and expanded through repetition not only discreet but also through systematic practice of nautical terminology communication between studentsthemselves; between students and teacher; between students and dialogue with powerpoint Listening comprehension like real improvised sessions on the acquisition of adeguat terminology of marine. (MARITIME ENGLISH)

\section{METHODOLOGY}

The methodology used is that of experimental and practical one. To make it function properly mass media and audiovisual technology, including here the television,computers are integrated in the most complete possible for the completion and in learning not only what is necessarily useful but also having fun in foreign language.

Descriptive categories, essays, assignments and course materials are also performed by students in connection with the individual independence, but they have been inseparable and matched to cyclic forms and in successive stages with the academic curriculum.

\section{PROBLEMS FACING WITH THE STUDENTS ALONG THE APPROPRIATION OF MARITIME -ENGLISH!}

\begin{tabular}{|c|c|c|}
\hline $\begin{array}{l}\text { 1) Problems of vocabulary and } \\
\text { communication with maritime - } \\
\text { English! }\end{array}$ & $\begin{array}{l}\text { 2) Problems of reading and } \\
\text { interpretation of specific English } \\
\text { (maritime)! }\end{array}$ & $\begin{array}{l}\text { 3) Problems in the English } \\
\text { language of grammatical } \\
\text { concepts! }\end{array}$ \\
\hline a) & a) & a) \\
\hline $\begin{array}{l}\text { Students distinguish and } \\
\text { understand the key issues of an } \\
\text { unknown content in the long texts } \\
\text { using complex sentences with some } \\
\text { repetition. } \\
\text { b) }\end{array}$ & $\begin{array}{l}\text { Students reveal strands of } \\
\text { independent reading, use context to } \\
\text { interpret the meaning and express a } \\
\text { personal response to reading. } \\
\text { They select by themselves and } \\
\text { extract information from text; }\end{array}$ & $\begin{array}{l}\text { Students express the right meaning } \\
\text { in response to orders, questions or } \\
\text { short and simple statements } \\
\text { directed in the classroom. } \\
\text { They themselves are reacting to } \\
\text { "Open / close" "Look... " "repeats" }\end{array}$ \\
\hline $\begin{array}{l}\text { Students search and provide } \\
\text { information and opinions for certain } \\
\text { conversations they show the ability } \\
\text { to adapt the language in } \\
\text { unpredictable situations in the sea. } \\
\text { c) } \\
\text { They adapt themselves to the } \\
\text { language of the scope and context, } \\
\text { discuss the reasons and }\end{array}$ & $\begin{array}{l}\text { Check up the accuracy and ask this } \\
\text { question: The direction river tug } \\
\text { how is pronounced? } \\
\text { b) } \\
\text { Students demonstrate increased } \\
\text { confidence in reading aloud and in } \\
\text { using and supporting reference }\end{array}$ & $\begin{array}{l}\text { b) Students express the meaning of } \\
\text { auxiliary forms } \\
\text { related to indicative situations that } \\
\text { teacher write on the blackboard to } \\
\text { clarify the meaning. E. g. } \\
\text { Ana : I know you ... }\end{array}$ \\
\hline
\end{tabular}


consequences if not done right the ship maneuvers and on the high seas.

Students discuss facts, ideas, and experiences having owned a great vocabulary, structures and confessions in diverse tenses.

They self - delineate its production of a real event taken from films or dramas.

They react to presenting facts and opinions from others.

They debate e. g. "It is changing the course of the ship by order of marine guard 371 . Will there be changes in new marine space?

\section{d)}

Students are involved freely in specialized conversations to their interest, they display certainty in contemporary knowledge, in place where the language is taught.

They discuss about the place where ships cross sea bounder

and change course guided by weather conditions and providing PRE-PERSONAL RECOMMENDATIONS material (fig 1/2/3/4). They begin to extend their independent reading.

They can disclose information from a brochure to refer the other, respond to such a request.

c)

Students express a full understanding of texts involving known or partially known vocabulary reflecting events in past, present and future. They can write a simple story based on the following model given for reading comprehension.

d)

Students express terms of the various texts involving composed sentences and unfamiliar vocabulary, they consult unknown reference materials;

such as the structure of the ship or different ships that perform functions such as icebreakers, aircraft carrier, ship deliberately offshore oil extraction, etc., (in the absence of Albanian dictionary)

-They give themselves e. $\mathbf{g}$.

-Ana- Which ships have the most powerful engines?

-Ben- Icebreakers have powerful engines and very strong hulls.

or they can be grab dredgers, which operate like cranes
Ben: You could be James, Bella's cousin.

c) Students write factual descriptions and creative compositions about their experiences using the appropriate structures.

They write about known topics related to complex verb time

- in present

-in past

-in future

And in sentence Structures, phrasal verbs, suffixes, kind of modal auxiliary verbs.

\section{Must/might/should/could}

- They give themselves e. $\mathbf{g}$

Ana: Ben-You should go to the dentist!! You could have an infected tooth, that's painful! 


\section{Specialised vessels}

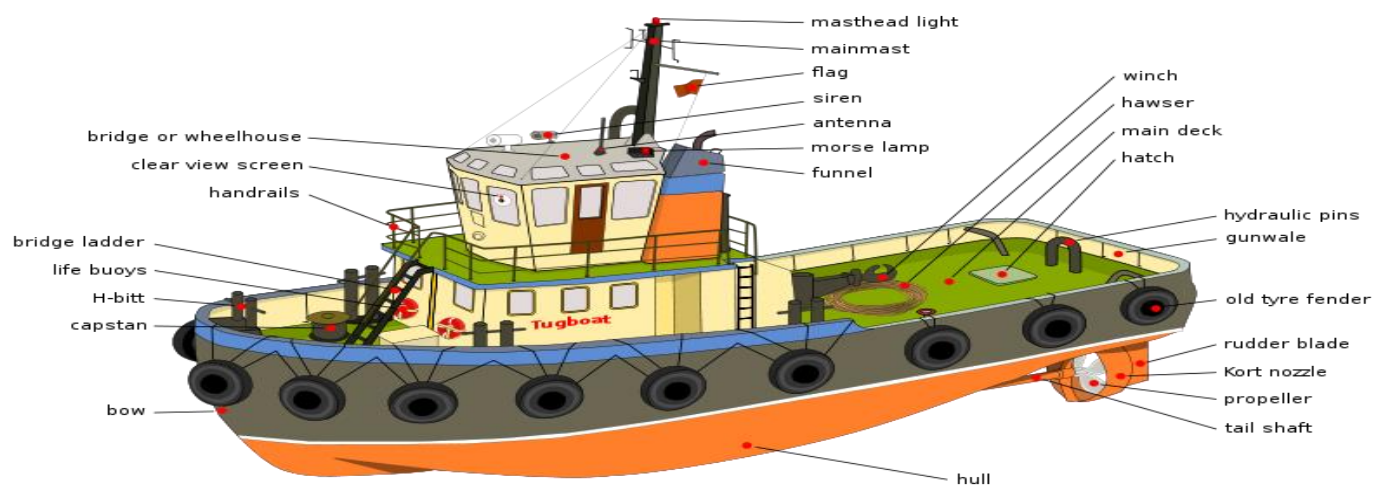

(fig 1)

One very useful type of vessel is the tug. They are divided in three basic types. A river tug is designed to work on inland waterways. Tugs must be designed to satisfy three important requirements: be stable in all conditions, be manoeuvrable and powerful enough to move ships of far greater size.

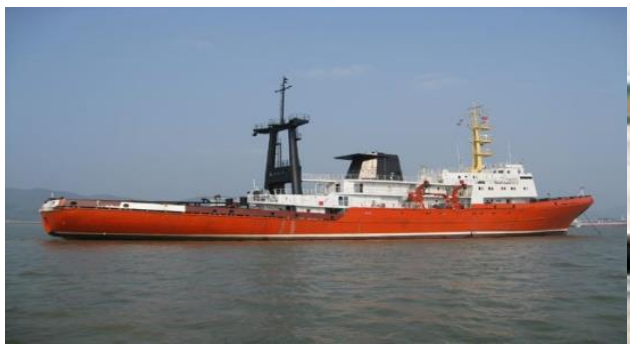

Ocean-going salvage tug (fig 2)

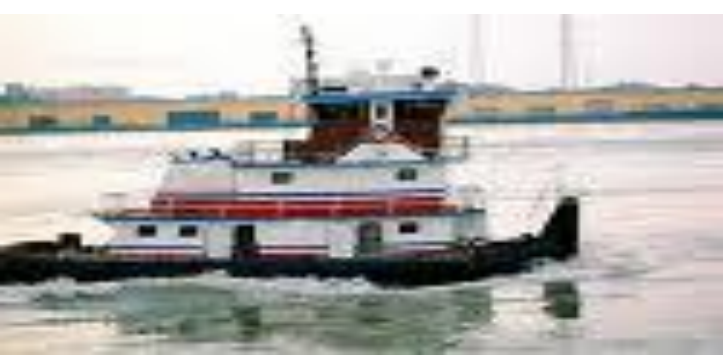

river tug/pusher(fig 3)

\section{Icebreaker}

Icebreaker is very important to shipping. Northern ports and channels freeze up in winter. Ships must use these ports all the year round, therefore it is necessary to keep them open. Icebreakers have powerful engines and very strong hulls.

\section{Lightship}

An unusual type of ship is the lightship. Lightships look like ordinary ships, but they do not have engines, because they are towed into position and then anchored there. They not only have a light, but also a foghorn, a radio beacon and meteorological equipment as well. Most lightships have a crew of approximately twelve.

\section{Dredgers}

Dredgers are necessary to remove the sand and mud from the beds of channels and harbours. It is a rather noisy and smaller type of vessel. Dredgers are of three main types: they can be either bucket dredgers, which have a series of buckets which go down to the sea bed and scoop up the sand and mud; they can be suction dredgers, which suck up the sand and mud like a very large vacuum cleaner; or they can be grab dredgers, which operate like cranes. 
bucket dredger grab dredger suction dredger(fig 4)

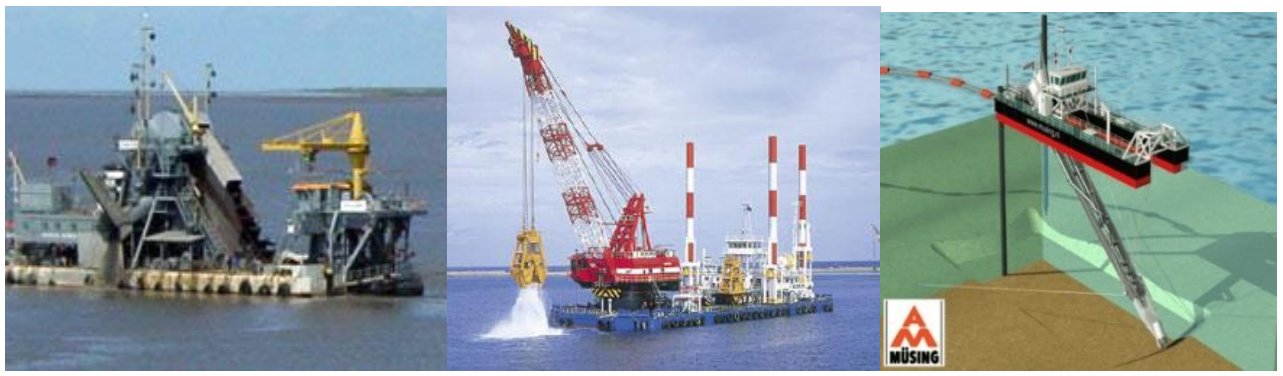

suction dredger(fig 4)

\section{Pilot Launch}

Pilot launches are motor boats for transporting pilots to and from ships.. They must be seaworthy as pilots go out in all weather. Fender system developed especially for this class ensures that minimal damage is suffered during the "controlled collisions" which characterizes pilot boarding operations.

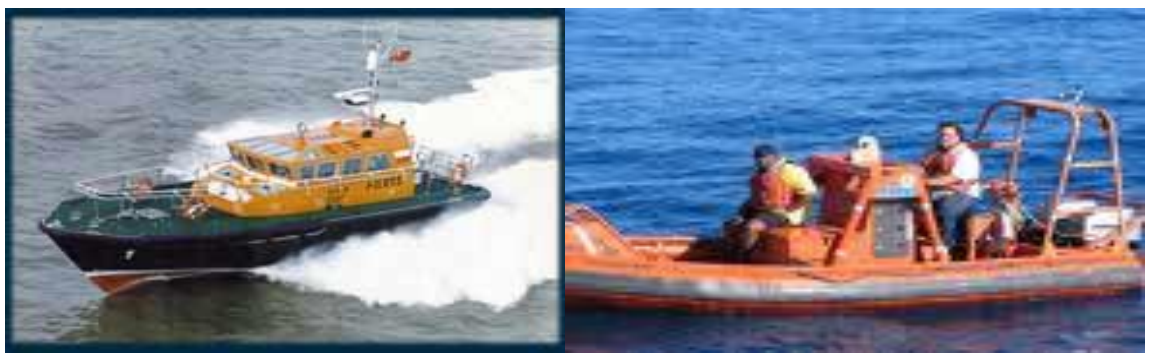

\section{Rescue lifeboat}

A rescue lifeboat is a boat designed and used with to attend a vessel in distress, or its survivors, to rescue crewmen and passengers. With its specialized features for searching for, rescuing and saving the lives of people in peril at sea or in estuaries, it can be hand-pulled, sail-powered or powered by an engine. Lifeboats may be rigid, inflatable or rigid-inflatable combination hulled vessels.

Let me specify the fact that the realization of the ideas from one class to another vary, I can say that even along the way to the class room teacher ideas change, even in parallel classes. In this case is worth cited "IF THE CHILD IS NOT LEARNING THE WAY YOU ARE TEACHING, THEN YOU MUST TEACH IN THE WAY THE CHILD LEARNS. " Ritta DUNN

\section{DE FACTO TEACHING CLASS}

SUBJECT: English Language, Specific for Marine Sciences

CODE: ENG 131-132

\section{CLASS: C-101 TECHNICAL ENGLISH}

TOPIC: Specialized vessels. Conditional sentences I-st $^{-5 n d}$ II-nd 


\section{General goals:}

The student along the lesson should know all the verbs in different tenses, mostly in the past tense.

The student must possess a considerable glossary for Maritime English referring to some information points that they have taken part before.

The student must understand the conditional sentence of type I and II

\section{TECHNICAL - CLASS AID.}

\begin{tabular}{|l|l|}
\hline Students tools & Teachers tools \\
\hline a- Student books and work books. & b- laptop with projector \\
\hline
\end{tabular}

\section{PROCEDURE OF THE TEACHING PROCESS}

Invdidual Strategies in fuction of the teaching process.

1) Once entered in the class proceed with the traditional greetings of the English class.

2) Some questions about previous rehearsal. Question (Flash) to let them know and to adjust them with the atmosphere of the English language. This enables them to speak freely English.

3) Students were distributed two sheets to check up the English tenses and Maritime competences. (Illustration below)

\begin{tabular}{|l|l|l|l|l|}
\hline Present simple & Past simple & Modals & Conditionals & Questions? \\
\hline $\begin{array}{l}\text { Sentence illustrations of } \\
\text { ship } \\
\text { with different disposition. }\end{array}$ & $\begin{array}{l}\text { Si ndryshon ne } \\
\text { Te shkuaren } \\
\text { E. g. The ship was } \\
\text { launched two days } \\
\text { ago. }\end{array}$ & $\begin{array}{l}\text { Modals can } \\
\text { should/could/might } \\
\text { E. g. You might lower the } \\
\text { lifeboat. }\end{array}$ & If.. I were & Free \\
& & & & \\
\hline
\end{tabular}

Flash card (1)

\begin{tabular}{|l|l|}
\hline COMPETENCE & KNOWLEDGE;UNDERSTANDING;PROFICIENCY \\
\hline $\begin{array}{l}\text { Use the IMO Standard Marine Communication Phrases and use } \\
\text { English in written and oral form. }\end{array}$ & $\begin{array}{l}\text { Adeqaute knowledge of the English language to enable } \\
\text { the officer... to communicate with other ships and coast } \\
\text { stations and and to perform the officer's duties also with } \\
\text { multilingual crew,including the ability to use.... the IMO } \\
\text { standard marine communication phrases. } \\
\text { 1)Basic communicative characteristics of the SMCP. } \\
\text {-vessels vs ships } \\
\text {-alter vs change (e. g. alter course) } \\
\text {-master vs captain } \\
\text { 2)Preferring Latinism/Internationalism } \\
\text {-assistance vs help }\end{array}$ \\
& 101
\end{tabular}




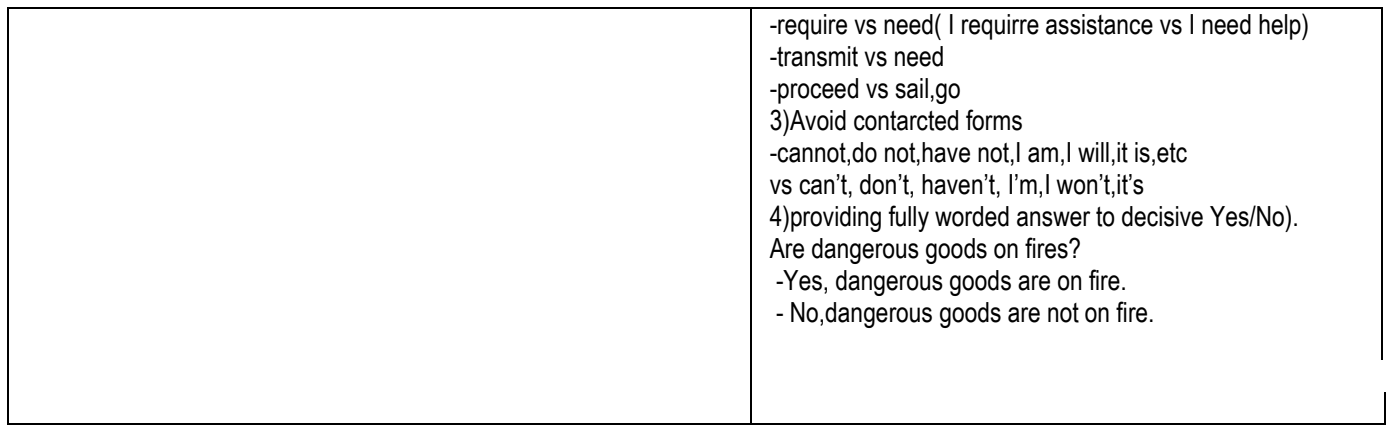

Flash card (2)

These Flash cards are given to students for 10 minutes. They can talk and fill in flash cards.

They begin to refer each other work, then they do questions to clarify those uncertainties. The teacher explain the appropriate item to be developed in the classroom about conditional sentence and terms taken on Maritime English.

4)Teacher explains on the blackboard conditional sentence of the first type. (Written with colored chalk) and allows students who according to examples given on the blackboard to adapt examples with information from flash cards in terms of Maritime English!

\section{FIRST CONDITIONAL}

It is practically used. It is expressed when we think something is possible to happen or not.

(we use first conditional when we think that $\mathrm{s} . \mathrm{m}$. th is probable or unlikely or happen)

If he is the captain, I'll ask him some help.

\section{SECOND CONDITIONAL}

We use the conditional sentence of the second type, when think laterally that something is impossible or bad to happen. (We use second conditional when we think that something is improbable or unlikely to happen)

If you sent an SOS, we would be safe very soon!

\section{SELF-ASSESSMENT:}

(Control of knowledge) In order to monitor the class and to practice conditional sentence sets the laptop part listening session for 2 minutes (a situation in ship). It has part of conditional sentence with modal verb.

In my personal belief and my experience as a human and then as a teacher, I know to express with complete certainty that if to someone (in our case stundet) is not given the right space to show who they are, what are their capabilities and talents, we can ever know how far the human being can go.

Consequently I assign the students a task to express thoughts, opinions and ideas by showing it within a poster or folder project.

For instance

Topic areas: International Marine World, Tourism 
Theme: Ships emergencies.

Act Communication and the Task:

Describe the activity of a ship rescue and environment

Functions: - Students prove themselves in the knowledge received

- Apply conditional grammar point

- Communicate in English Studies and undertakes responsibilities of communication under the International Regulation Sea IMO.

Presenting in group

\section{CONCLUSIONS}

As far as Maritime Education and learning takes a considerable time with students. It has been observed that teaching Maritime English courses in University auditorium is really effective because it fulfil the demands of contemporary communication specifically in the sea; But it is also observed that there is a lack of professional development courses available for teachers to develop or upgrade the skills necessary to provide a high standard of training. The teaching incorporates individual professional interests and needs of the students. Knowledge are assessed with the modules of selected maritime English in order to best equip the a) students b) other participants with effective language acquisition.

Accordingly, to both sides of students and teachers really need more professional engagements in Teaching and administering Maritime English courses

- Teaching General English may move into teaching Maritime English;

- Teaching specialist maritime subjects through English, for example, for students, for former seafarers where English is the means of instruction and global communication has its own difficulties. That's a time challenge that is upon our academic task in near future!

\section{REFERENCE}

Bahns,H., (1993) Lexical collocations: a contrastive view, University of Kiel, Germany (pp. 14)

Baker, C., (1992) Attitudes and language. Clevedon, USA. (pp. 53)

Curtius 1972: Curtius, E,R (1972) Evropska knjizevnost i latinsko srednjovjekovlje, Zagreb (p. 326. )

Hatim \& Mason, (1990) Characterising the Genre of the Corporate Press Release, University of Heriot Watt, Edinburg, U. K. (pp. 204-203)

John H. Flavell, (1997) Development of knowledge about vision, University of Birmingham, (pp. 72. )

Orbaneja y Majada, Linguistic perspectives from the classroom: Language teaching in a Multicultural Europe, 1998: $362-$ 363.

Newmark, (1988) Approaches to translations, Prentince Hall, Indiana University (pp. 213)

Sinclair, J., (1991)“Corpus concorde, collocation: Describing English Language”, Oxford University Press (pp. 112)

"Webster New World Dictionary" (Third College Edition, 1988). 